\title{
Skull morphometrics of adult male Antartic fur seal, Arctocephalus gazella, and South American fur seal A. australis
}

\author{
Gustavo A. Daneri ${ }^{1}$, César M. García Esponda², Luciano J. M. De Santis ${ }^{2}$ \& Laura Pla $^{3}$
}

1. Museo Argentino de Ciencias Naturales "Bernardino Rivadavia", División Mastozoología, Av. Angel Gallardo 470, (C1405DJR) Buenos Aires, Argentina. (gadaneri@yahoo.com.ar; gdaneri@macn.gov.ar)

2. Museo de La Plata, Cátedra de Anatomía Comparada, Paseo del Bosque, (1900) La Plata, Argentina.

3. Universidad Nacional Experimental Francisco de Miranda, Departamento de Ambiente y Tecnología Agrícola, Apartado 7434, Coro 4101, Falcón-Venezuela

\begin{abstract}
The skull morphometrics of adult male Antarctic fur seal, Arctocephalus gazella (Peters, 1875) and South American fur seal, A. australis (Zimmermann, 1783) were investigated using a collection of 45 and 38 skulls, respectively. Eighteen measurements were taken for each specimen. Comparative univariate and multivariate statistical analyses included standard statistics, one-way analysis of variance, principal component analysis and discriminant analysis. Individual variation was relatively high for some variables, as expressed by the coefficient of variation. Skulls of A. gazella were larger than those of A. australis for all but two variables: squamosal jugal suture and rostral length. Both species differed significantly as shown by both univariate and multivariate analyses. The discriminant function correctly classified all specimens. The standardized canonical coefficients showed that the variables which most contribute to the differentiation between species were, in decreasing order, the rostral length, palatal length, palatal width at postcanine 5 and braincase width. The present study corroborates that A. gazella and A. australis are phenotipically distinct species.
\end{abstract}

KEYWORDS. Arctocephalus, Otariidae, cranial characteristics.

RESUMEN. Morfometría craneana comparada de ejemplares machos adultos de lobo fino antártico, Arctocephalus gazella y lobo fino sudamericano, A. australis. Se estudió la morfometría craneana de especímenes machos adultos de lobo fino Antártico, Arctocephalus gazella (Peters, 1875) y lobo fino sudamericano, A. australis (Zimmermann, 1783), consultando una colección de 45 y 38 cráneos respectivamente. Para cada ejemplar se tomó un total de 18 medidas. El análisis comparativo univariado y multivariado incluyó estadística standard, análisis de varianza, análisis de componentes principales y análisis discriminante. La variación individual, según lo expresado por el coeficiente de variación, fue relativamente alta para algunas variables. Los cráneos de A. gazella fueron proporcionalmente más grandes que aquellos de A. australis para todas las variables estudiadas, excepto dos: longitud de la sutura escamoso-yugal y longitud rostral. Tanto el análisis uni como mutivariado indicaron que ambas especies difieren significativamente. La función discriminante clasificó correctamente a todos los especímenes estudiados. Los coeficientes canónicos estandarizados revelaron que las variables que más contribuyeron a la diferenciación entre las especies fueron, en orden decreciente, la longitud rostral, longitud palatal, ancho palatal a nivel del postcanino 5 y ancho de la caja craneana. El presente estudio corrobora que A. gazella y A. australis son claramente especies fenotípicamente distintas.

PALABRAS-CLAVE. Arctocephalus, Otariidae, características craneanas.

The polytipic genus Arctocephalus comprises eight species of fur seals which are mainly distributed in the southern hemisphere with the exception of the Guadalupe fur seal, A. townsendi Merriam, 1897, which is known from Isla Guadalupe, Mexico $\left(29^{\circ} \mathrm{N}\right)$ and nearby islands (REPENNING et al., 1971). Of the southern species, three are partially distributed in the Atlantic sector of the Southern Ocean, i.e., the South American fur seal, A. australis (Zimmermann, 1783), the Subantarctic fur seal, A. tropicalis (Gray, 1872) and the Antarctic fur seal, A. gazella (Peters, 1875) (KING, 1983). The two former species partially overlap in their distributional range, and hybridization between them has been reported (ConDY, 1978; KeRLEY \& RoBinson, 1987). In contrast, A. gazella and $A$. australis present separated geographical ranges, with the former species distributed to the south and the latter to the north of the Antarctic Polar Front. However, vagrant individuals of both species have been reported crossing this natural barrier (CSORDAS, 1962; PAYNE, 1979; Pinedo, 1990; DANERI et al., 1997; Oliveira et al., 2001).

Regarding skull morphometrics, previous studies have shown a marked degree of variation and overlap in skull measurements within and among species of Arctocephalus (e. g. Sivertsen, 1954; KING, 1969). REPENNING et al. (1971) stated that several species of Arctocephalus were distinguishable on the basis of suites of cranial measurements and considered that skull length, rostral length, nasal length, height of forehead and width of palate between postcanines were most useful for their identification. Additionally, tooth size and pattern were also found to be important characters for distinguishing species. However, they admitted the existence of great intraspecific variation for each of these skull measurements. Moreover, as pointed out by BRUNNER (1998a), the main problems found in taxonomic studies of fur seals are related to small sample sizes, and the lack of quantitative information on variation of the morphology within species. These problems have usually led to either erroneous specific identifications or misleading conclusions on the taxonomic relationships among species of Arctocephalus. For instance, KING (1954), based on the analysis of only three fur seal skulls from Galapagos Islands, assigned them tentatively to the species A. australis. The same author, after comparing 
measurements and proportions of two skulls of Arctocephalus philippii (Peters, 1866) and one of $A$. townsendi, concluded that these species are very similar to each other and should be synonymized under the name A. philippii, wich has priority. However, REPENNING et al. (1971) recognized the Galapagos fur seal as a full species, Arctocephalus galapagoensis Heller, 1904, and also proposed the specific separation of the Juan Fernandez and Guadalupe fur seals as A. philippii and A. townsendi respectively. To the present, skull morphometric studies within and among fur seal species based on a relatively large number of specimens and employing multivariate analysis techniques have been scarce (e. g. BRUNNER, 1998a; Kerley \& Robinson, 1987; OliveIRA et al., 1999; KeRLEY et al., 2000). Additionally, no comparative study of this type has been performed between the Southern fur seal, A. australis and the Antarctic fur seal, A. gazella. Therefore, the aim of the present study is to examine the skull differences between adult males of these two fur seal species as well as their intraspecific variability by means of univariate and multivariate analyses.

\section{MATERIAL AND METHODS}

This study was based on 83 male skulls of two species of fur seals of the genus Arctocephalus: A. gazella $(\mathrm{n}=45)$ and $A$. australis $(\mathrm{n}=38)$. All A. gazella skulls came from South Orkney and South Shetland Islands, except one specimen from South Georgia, while those of A. australis were collected on islands and mainland coasts of the Southwest Atlantic. Specimens were examined from the collections of the Museo de La Plata, Departamento Científico Zoología Vertebrados, División Mastozoología, La Plata (MLP); Museo Argentino de Ciencias Naturales "Bernardino Rivadavia”, División Mastozoología, Buenos Aires (MACN-Ma); Instituto Antártico Argentino, Buenos Aires (IAA); Museo Nacional de Historia Natural, Montevideo (MNHN) and Facultad de Ciencias, Zoología Vertebrados Colección Mamíferos, Montevideo (ZVCM).

Only male skulls were included in the study as no female skulls of A. gazella were available from the above collections. Sex was taken from specimen labels.

Specimens were aged on the basis of a suture index (SI) following SiVERTSEN (1954), who considered as adults those with SI 19-36. However, BRUNNER (1998a), analyzing the skull morphometrics of two species of fur seals, Arctocephalus pusillus (Schreber, 1776) and A. forsteri, considered that adult males that had reached physiological maturity (when condylobasal length no longer increases) were those with suture index of at least 24 . Therefore, we included for statistical analyses only individuals of SI 24 or more.

A total of 18 measurements (Fig. 1) were taken for each skull using a dial caliper to the nearest $0.1 \mathrm{~mm}$. Measurements corresponded to those used in previous otariid studies (Sivertsen, 1954; Kerley \& Robinson, 1987; Brunner, 1998a,b; Kerley et al., 2000): Condylobasal length (CBL), zygomatic width (ZW), braincase width (BW), mastoid width (MW), interorbital width (IOW), supraorbital width (SOW), preorbital width
(POW), rostral length (RL), squamosal-jugal suture length (S-JL), zygomatic root width (ZRW), palate width at postcanine 1 (PW1), palate width at postcanine 3 (PW3), palate width at postcanine 5 (PW5), upper postcanine length (UPCL), palatal length (PL), occipital crest-mastoid (OC-M), auditory width (AW) and distance between basion and bend of pterygoid (B-PT).

Some traditional measurements (e. g. rostral width, length and width of nasals) were not included in the analyses since many skulls had these structures damaged. Mandibular measurements were also excluded due to the lack of the mandible in many skulls of $A$. australis.

Univariate and multivariate statistical analyses were performed using the statistical software package Statistica (v. 5.5) (STATSOFT, 1999). Standard statistics comprised mean, standard deviation, coefficient of variation $(\mathrm{CV})$ and range. Also, one-way analysis of variance on each character was used to ascertain whether or not significant differences existed among species. Interspecific differences were also investigated for each character using the percentage difference between means (\% D) (KING \& Moody, 1982; ReIG \& RuPRECHT, 1989); the mean for these percentages ( $\overline{\mathrm{x}} \% \mathrm{D}$ ) was also calculated.

Since multivariate analyses require complete data sets, those missing cranial measurements of each specimen were estimated by stepwise regression from the remaining subset of cranial variables available for this specimen (REIG \& RupReCHT, 1989; ReIG, 1992). Estimates were made separately for each species and the predicted values were then filled in the data matrix. Fourteen estimated measurements were included representing $1.04 \%$ of total data. Following KERLEY \& ROBINSON (1987) those variables showing relatively high CVs $(>9 \%)$ were excluded from further multivariate analysis. These were S-JL, ZRW, PW3 and SOW.

A principal component analysis (PCA) and a discriminant function analysis were performed on $\log$ transformed data in order to investigate morphological variation within each group and to examine relationships between species.

For the PCA, the values of the original variables were standardized to $\mathrm{z}$ scores so that each variable had equal weight. This procedure removes bias resulting from larger measurements being dominant over the smaller (BRUNNER 1998a, 2002). The standard method of the Statistica (v. 5.5) program, which includes all variables in the discriminant analysis, was used. The standardized canonical coefficients, which represent the contribution of each variable to the discriminant function, were inspected in order to investigate the group differences.

Specimens examined. Arctocephalus gazella (45): South Georgia, MACN-Ma 16512; Laurie Island, South Orkney Islands, MACN-Ma 21060, 21061, 21349 - 21351, 21860 MLP 25.VI.02.8 - 21, IAA 9 - 12, 14 - 17; King George Island, South Shetland Islands, MACN-Ma 20436, 21062, 21353, 21754 21756, 21760 MLP 25.VI.02.22, IAA 1 - 5; Nelson Island, South Shetland Islands, MACN-MA 21757, 21758; Halfmoon Island, South Shetland Islands, MLP(DZV) 25.VI.02.24

Arctocephalus australis (38): URUGUAY, Cabo Polonio, MNHN 3199, ZVCM 349, 353, 358, 1535, 1544; Balneario Atlántico, ZVCM 1542; Dep. Rocha (exact locality unknown), ZVCM 1317; Arroyo Chuy, ZVCM 1519; Barra del Arroyo 

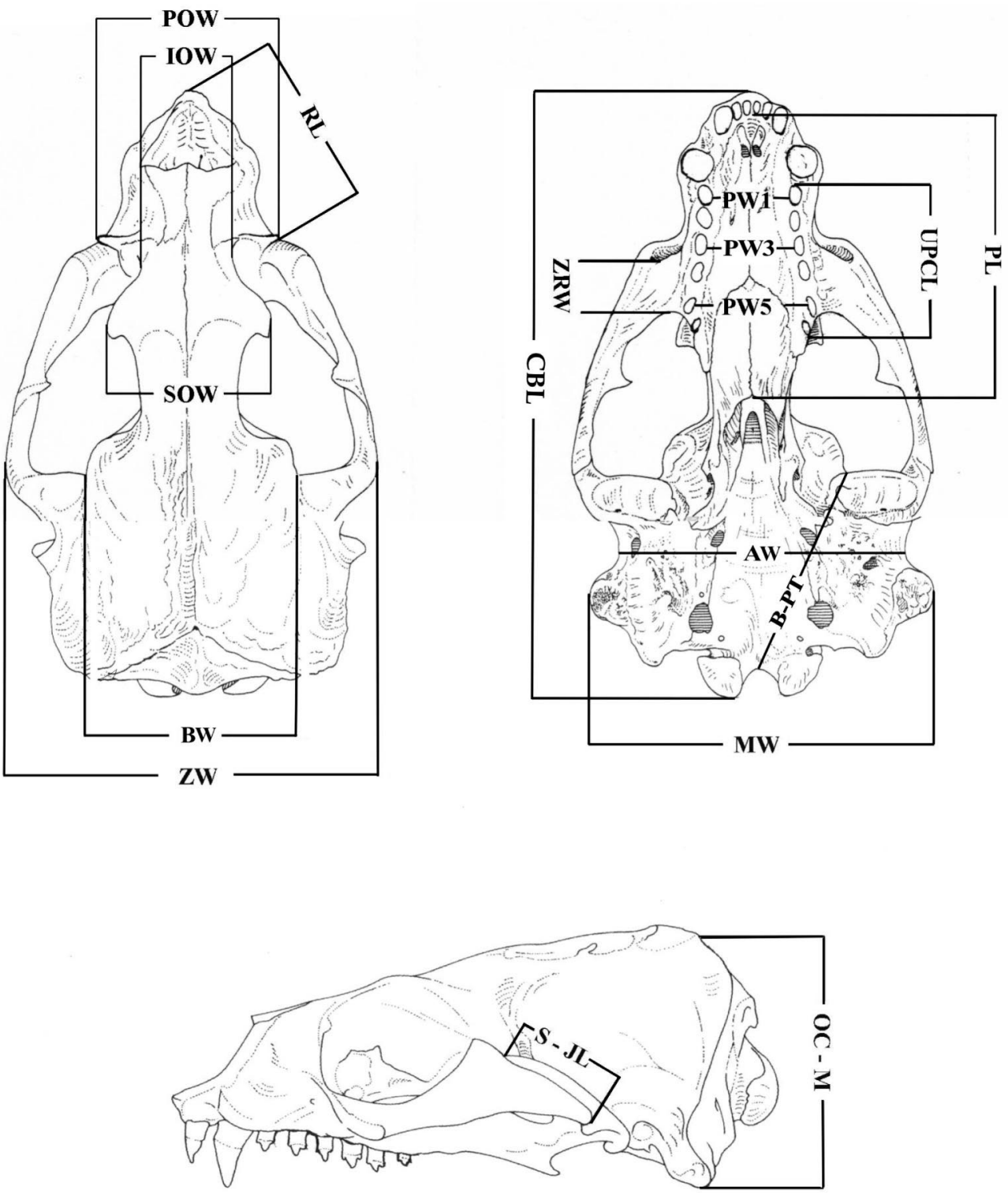

Fig. 1. Skull measurements used in this study (AW, auditory width; B-PT, distance between basion and bend of pterigoyd; BW, braincase width; CBL, condylobasal length; IOW, interorbital width; MW, mastoid width; OC-M, occipital crest-mastoid; PL, palatal length; POW, preorbital width; PW1, palate width at postcanine1; PW3, palate width at postcanine 3; PW5, palate width at postcanine 5; RL, rostral length; S-JL, squamosal-jugal suture length; SOW, supraorbital width; UPCL, upper postcanine length; ZRW, zygomatic root width; ZW, zygomatic width).

Maldonado, ZVCM 1520; Playa Buceo, MNHN 2950; Isla de Lobos, Uruguay, MNHN 2495, 2496, 2529, ZVCM 27; Uruguayan coasts (exact locality unknown), ZVCM, 12, 351, 359, 361, $362,1518,1537,1543,1546,1549,1550,1557,1591,2129$, 2130, 2131, 2562; ARGENTINA, Santa Teresita, MACN-Ma 20566; Mar del Plata, MLP 1061; Malvinas/Falkland Islands, MACN-Ma 21863; South Georgia, MACN-Ma 29.769; unknown locality, MLP 14-IV-48-14, MACN-Ma 20562.

\section{RESULTS}

On average, skulls of $A$. gazella were larger $(\overline{\mathrm{x}} \%=$ 9,7) than those of $A$. australis for almost all dimensions except for squamosal-jugal suture length and rostral length. Palate width at postcanine 5 and zygomatic root width were the characters with the highest value of percentage of difference among species; nevertheless, all measurements showed an overlap in ranges. Individual variation, expressed by the coefficients of variation $(\mathrm{CV})$, was relatively high for some variables in both species (Tab. I).

Univariate analyses of variance were carried out including estimated values, in order to make $F$ values comparable (i. e. with the same degrees of freedom). The tests revealed highly significant differences between species in all variables $(\mathrm{P}<0.001)$, with the exception of rostral length $(\mathrm{P}>0.05$, Tab. I). Palate width at postcanine 
5, palatal length and zygomatic root width showed the most significant difference (highest $\mathrm{F}$ values) between species (Tab. I). The PCA performed for A. gazella revealed that the percentage of total variance that best explained the data was summarized in the first three components. Component I accounted for $46.2 \%$ of the total variation and was interpreted as a size component as suggested by the relatively large and positive coefficients for almost all measurements. Component II accounted for a further $11.9 \%$ of the total variation and was described as a shape component because of their positive and negative coefficients. This component was mainly influenced by upper postcanine length, palatal length and auditory width. Component III, also a shape component, accounted for a further $8.2 \%$ of total variation and was influenced mainly by interorbital width and palatal width at postcanine 5 (Tab. II). Eigenvalues for components I, II and III were 6.46, 1.66 and 1.14 respectively.

On the other hand, PCA for A. australis showed that Component I related to size and accounted for $45.3 \%$ of the total variation. Component II, a shape component, accounted for a further $11.5 \%$ of the total variation and was influenced by braincase width, interorbital width and palatal width at postcanine 5. Component III, also a shape component, accounted for $9.7 \%$ of the total

Table I. Basic statistics (in mm) of 18 skull measurements (see the text for explanation of abbreviations) of Arctocephalus gazella and A. australis. The percentage of difference between means (\% D) and their mean (**) are also given. F values were calculated from complete data set (including estimated values); all variables showed significant differences $(\mathrm{P}<0.001)$ between species, except RL $(*$, $\mathrm{P}=0.38)$; degrees of freedom: 1.81 .

\begin{tabular}{|c|c|c|c|c|c|c|c|c|c|c|}
\hline \multirow[b]{2}{*}{ Variable } & \multicolumn{3}{|c|}{ A. gazella } & \multicolumn{5}{|c|}{ A. australis } & \multirow[b]{2}{*}{$\% \mathrm{D}$} & \multirow[b]{2}{*}{$\mathrm{F}$} \\
\hline & $\mathrm{N}$ & Mean \pm SD & Range & $\mathrm{CV}$ & $\mathrm{N}$ & Mean \pm SD & Range & $\mathrm{CV}$ & & \\
\hline$\overline{\mathrm{CBL}}$ & 44 & $245.57 \pm 7.29$ & $226.3-262.7$ & 3.0 & 38 & $237.44 \pm 8.16$ & $221.9-258.8$ & 3.4 & 3.4 & 23.8 \\
\hline $\mathrm{ZW}$ & 45 & $147.98 \pm 5.73$ & $132.8-162.9$ & 3.9 & 38 & $138.67 \pm 5.17$ & $125.8-149.1$ & 3.7 & 6.7 & 59.5 \\
\hline BW & 45 & $81.38 \pm 3.27$ & $75.4-91.4$ & 4.0 & 38 & $76.00 \pm 2.50$ & $69.7-80.9$ & 3.3 & 7.1 & 71.3 \\
\hline MW & 45 & $138.46 \pm 6.25$ & $125.0-154.2$ & 4.5 & 38 & $128.29 \pm 6.13$ & $112.7-144.8$ & 4.8 & 7.9 & 56.5 \\
\hline AW & 45 & $118.2 \pm 5.0$ & $107.9-128.4$ & 4.3 & 38 & $114.1 \pm 5.1$ & $103.7-123.6$ & 4.5 & 6.1 & 37.6 \\
\hline IOW & 43 & $37.21 \pm 2.49$ & $31.6-43.2$ & 6.7 & 38 & $34.77 \pm 2.72$ & $31.0-43.7$ & 7.8 & 7.0 & 16.9 \\
\hline SOW & 42 & $63.85 \pm 4.87$ & $51.1-73.5$ & 7.6 & 35 & $54.25 \pm 6.00$ & $43.4-69.0$ & 11.1 & 17.7 & 74.0 \\
\hline POW & 45 & $66.66 \pm 3.73$ & $56.6-74.5$ & 5.6 & 35 & $62.23 \pm 3.82$ & $53.6-70.4$ & 6.1 & 7.1 & 30.8 \\
\hline RL & 45 & $75.18 \pm 3.60$ & $66.8-85.4$ & 4.8 & 38 & $75.84 \pm 3.33$ & $67.5-83.0$ & 4.4 & -0.9 & $0.8 *$ \\
\hline S-JL & 45 & $34.81 \pm 3.29$ & $27.6-43.2$ & 9.4 & 38 & $37.65 \pm 2.88$ & $29.8-43.1$ & 7.6 & -7.6 & 17.4 \\
\hline ZRW & 45 & $21.48 \pm 1.97$ & $16.2-25.7$ & 9.2 & 38 & $17.05 \pm 1.52$ & $13.8-19.8$ & 8.9 & 26 & 129.4 \\
\hline PW 1 & 45 & $29.23 \pm 2.41$ & $23.9-35.2$ & 8.2 & 38 & $25.92 \pm 2.31$ & $21.6-31.7$ & 8.9 & 12.8 & 40.7 \\
\hline PW 3 & 45 & $31.8 \pm 2.6$ & $26.9-38.2$ & 8.2 & 38 & $28.1 \pm 2.7$ & $23.4-34.9$ & 9.5 & 13 & 40.3 \\
\hline PW 5 & 44 & $42.55 \pm 3.39$ & $34.7-51.0$ & 8.0 & 38 & $33.20 \pm 2.59$ & $27.9-37.4$ & 7.8 & 28.2 & 204.2 \\
\hline UPCL & 42 & $65.08 \pm 3.14$ & $58.2-72.4$ & 4.8 & 36 & $58.55 \pm 2.83$ & $54.1-65.7$ & 4.8 & 11.1 & 105.1 \\
\hline PL & 45 & $112.91 \pm 5.47$ & $95.4-123.0$ & 4.8 & 37 & $99.76 \pm 4.30$ & $91.0-108.6$ & 4.3 & 13.2 & 143.5 \\
\hline $\mathrm{B}-\mathrm{PT}$ & 44 & $84.6 \pm 2.9$ & $78.6-91.0$ & 3.5 & 38 & $80.0 \pm 2.9$ & $74.4-85.9$ & 3.6 & 5.7 & 52.5 \\
\hline \multirow[t]{2}{*}{ OC-M } & 45 & $118.92 \pm 6.46$ & $103.3-133.7$ & 5.4 & 38 & $108.24 \pm 5.82$ & $95.7-120.1$ & 5.4 & 9.9 & 61.9 \\
\hline & & & & & & & & \multicolumn{3}{|c|}{$9.7 * *$} \\
\hline
\end{tabular}

Table II. Factor matrix from the 14 variable principal component analysis of specimens of $A$. gazella showing the character loadings on the first three components.

\begin{tabular}{lccc}
\hline Variable & Factor & Factor & Factor \\
& 1 & 2 & 3 \\
\hline CBL & 0.83 & 0.31 & -0.05 \\
ZW & 0.81 & -0.34 & 0.21 \\
BW & 0.25 & 0.34 & 0.38 \\
MW & 0.78 & -0.36 & 0.25 \\
IOW & 0.67 & -0.30 & -0.48 \\
POW & 0.67 & -0.27 & -0.39 \\
RL & 0.80 & 0.28 & 0.18 \\
PW 1 & 0.70 & 0.16 & -0.30 \\
PW 5 & 0.58 & -0.04 & -0.42 \\
PL & 0.59 & 0.47 & 0.07 \\
AW & 0.73 & -0.39 & 0.40 \\
B-PT & 0.63 & 0.32 & 0.04 \\
OC-M & 0.78 & -0.25 & 0.20 \\
UPCL & 0.45 & 0.63 & -0.09
\end{tabular}

Table III. Factor matrix from the 14 variable principal component analysis of specimens of $A$. australis showing the character loadings on the first three components.

\begin{tabular}{lccc}
\hline Variable & Factor & Factor & Factor \\
& 1 & 2 & 3 \\
\hline CBL & 0.85 & 0.07 & 0.00 \\
ZW & 0.86 & -0.07 & 0.12 \\
BW & -0.02 & 0.67 & 0.60 \\
MW & 0.82 & -0.34 & 0.00 \\
IOW & 0.55 & 0.44 & 0.45 \\
POW & 0.64 & 0.34 & 0.03 \\
RL & 0.79 & 0.18 & -0.08 \\
PW 1 & 0.51 & 0.37 & -0.57 \\
PW 5 & 0.38 & 0.43 & -0.64 \\
PL & 0.63 & -0.39 & 0.08 \\
AW & 0.81 & -0.22 & 0.01 \\
B-PT & 0.51 & 0.20 & 0.02 \\
OC-M & 0.84 & -0.35 & 0.19 \\
UPCL & 0.68 & -0.05 & 0.02 \\
\hline
\end{tabular}


variation and was influenced primarily by palate width at postcanine 5 , braincase width and palate width at postcanine 1 (Tab. III). Eigenvalues for components I, II and III were $6.33,1.60$ and 1.35 respectively.

Additionally, a PCA for both species combined i.e without prior grouping of material, was performed. In this case, the total variation of the pooled data was summarized in two components. Component I, a size component, with all positive (mostly large) coefficients, accounted for $61.5 \%$ of the total variation. Component II accounted for another $9 \%$ of the total variation being mainly influenced by rostral length, braincase width and palate width at postcanine 5 (Tab. IV). Eigenvalues for components I and II were 8.60 and 1.26 respectively.

The diagram illustrating the pairwise comparison of components I and II shows a clear and good separation between the two species (Fig. 2) .

Finally, the discriminant function analysis indicated significant differences among species $(\mathrm{W}=0.10 ; \mathrm{F}=39.87$; d. f. $\left.=14,68 ; \mathrm{P}<0.0001, \mathrm{D}^{2}=33.06\right)$. The function correctly classified all specimens and the derived discriminant scores plotted as frequency histograms clearly illustrate

Table IV. Factor matrix from the 14 variable principal component analysis of specimens of both species of Arctocephalus combined showing the character loadings on the first two components.

\begin{tabular}{lcc}
\hline Variable & Factor & $\begin{array}{c}\text { Factor } \\
\text { II }\end{array}$ \\
\hline CBL & 0.84 & -0.30 \\
ZW & 0.90 & -0.08 \\
BW & 0.62 & 0.47 \\
MW & 0.87 & -0.09 \\
IOW & 0.69 & -0.18 \\
POW & 0.77 & -0.11 \\
RL & 0.43 & -0.78 \\
PW 1 & 0.77 & 0.02 \\
PW 5 & 0.82 & 0.39 \\
PL & 0.84 & 0.22 \\
AW & 0.84 & -0.08 \\
B-PT & 0.77 & 0.08 \\
OC-M & 0.88 & -0.08 \\
UPCL & 0.81 & 0.27 \\
\hline
\end{tabular}

Table V. Standardized coefficients and eigenvalue of the discriminant function separating adult males of A. gazella and A. australis.

\begin{tabular}{lc}
\hline Variable & $\begin{array}{c}\text { Standardized } \\
\text { Coefficients }\end{array}$ \\
\hline CBL & -0.38 \\
ZW & 0.28 \\
BW & 0.45 \\
MW & 0.30 \\
IOW & -0.05 \\
POW & 0.06 \\
RL & -0.83 \\
PW 1 & 0.06 \\
PW 5 & 0.51 \\
PL & 0.59 \\
AW & -0.39 \\
B-PT & 0.28 \\
OC-M & 0.25 \\
UPCL & 0.22 \\
Eigenval & 8.21 \\
\hline
\end{tabular}

the separation between the two species (Fig. 3). Examination of the standardized canonical coefficients revealed that the variables which most contributed to the discrimination between groups, in decreasing order, were rostral length, palatal length, palatal width at postcanine 5 and braincase width (Tab. V).

\section{DISCUSSION}

Fur seals of both species exhibited a relatively high variation, expressed by the coefficients of variation (CV) in some cranial measurements. High CVs have been also reported in previous morphometric studies of Arctocephalus species (e. g. KerLey \& RoBinson, 1987; Brunner, 1998a; Kerley et al., 2000). This general variability may be a feature of marine mammals and, as KERLEY \& RoBINSON (1987) suggested, this should be taken into account when variables are selected for analysis. Skulls of male A. gazella are larger than those of $A$. australis in almost all dimensions. The two species differ significantly in all but one variable, the rostral length, as shown by one-way ANOVA. However, when this variable was considered in correlation with the others, it made a significant contribution to the discrimination between species, as shown by the standardized coefficients of the discriminant analysis as well as by the PCA combined for both species. In relation to this character, it is worth mentioning that the rostrum of $A$. gazella was described by REPENNING et al. (1971) as distinctively broad and rather short while that of $A$. australis is moderately long . Additionally, we observed that A. gazella presents a wider palate than A. australis. The tooth row of the former species is characterized by a posterior divergence, especially at the level of the fifth postcanine teeth. In A. australis, the tooth rows are roughly parallel and there is only a slight divergence at the level of the fifth postcanine. This is in line with the great contribution of the palatal width at postcanine 5 to the differentiation between both species found in this study. The squamosal-jugal suture as well as the zygomatic root width were mentioned by KING (1959) as two of the three most useful characters for distinguishing A. gazella from A. tropicalis. However, KeRLey \& RoBINSON (1987) excluded them from their study because they considered that these variables exhibited high intraspecific variation or high interspecific overlap, not being suitable for taxonomic purposes. Other characters also excluded under the same criteria by these authors were supraorbital width and rostral length (gnathion to preorbital process length sensu KERLEY \& RoBINSON, 1987). In the present study these same characters, together with palatal width at postcanine 3 , were also excluded from multivariate analysis because of their high CVs with the exception of rostral length, which presented a $\mathrm{CV}<5 \%$.

REPENNING et al. (1971) stated that, despite the great individual variation in skull measurements, postcanine teeth probably provided the easiest key to the identification of fur seal species. According to these authors the teeth of $A$. australis present either prominent anterior and posterior cusps or a single main cusp with a suggestion of an anterior accessory cusp. Also, a weak diastema is present between the fifth and sixth 


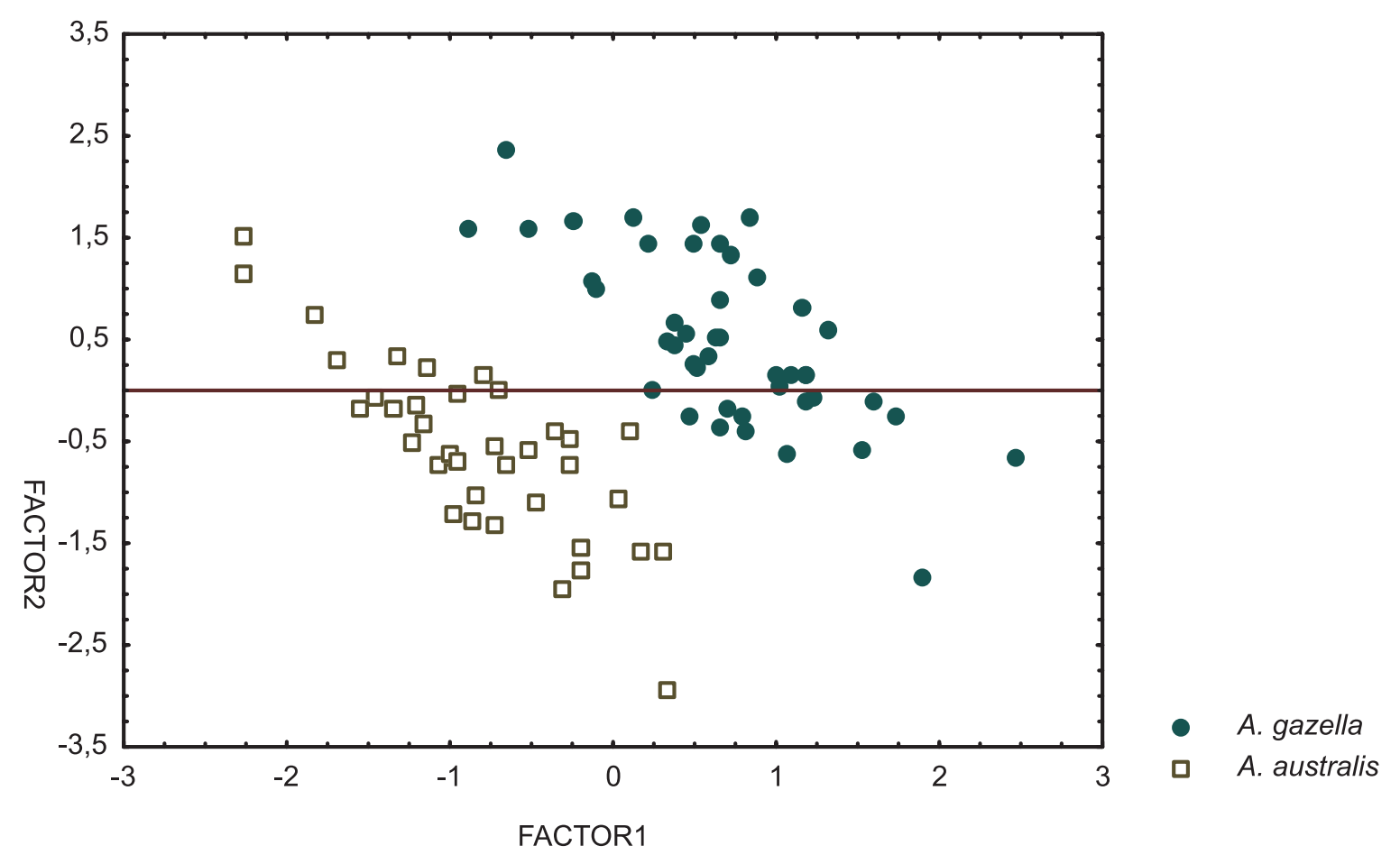

Fig. 2. Pairwise comparison of factors I and II from the principal component analysis of Arctocephalus specimens.

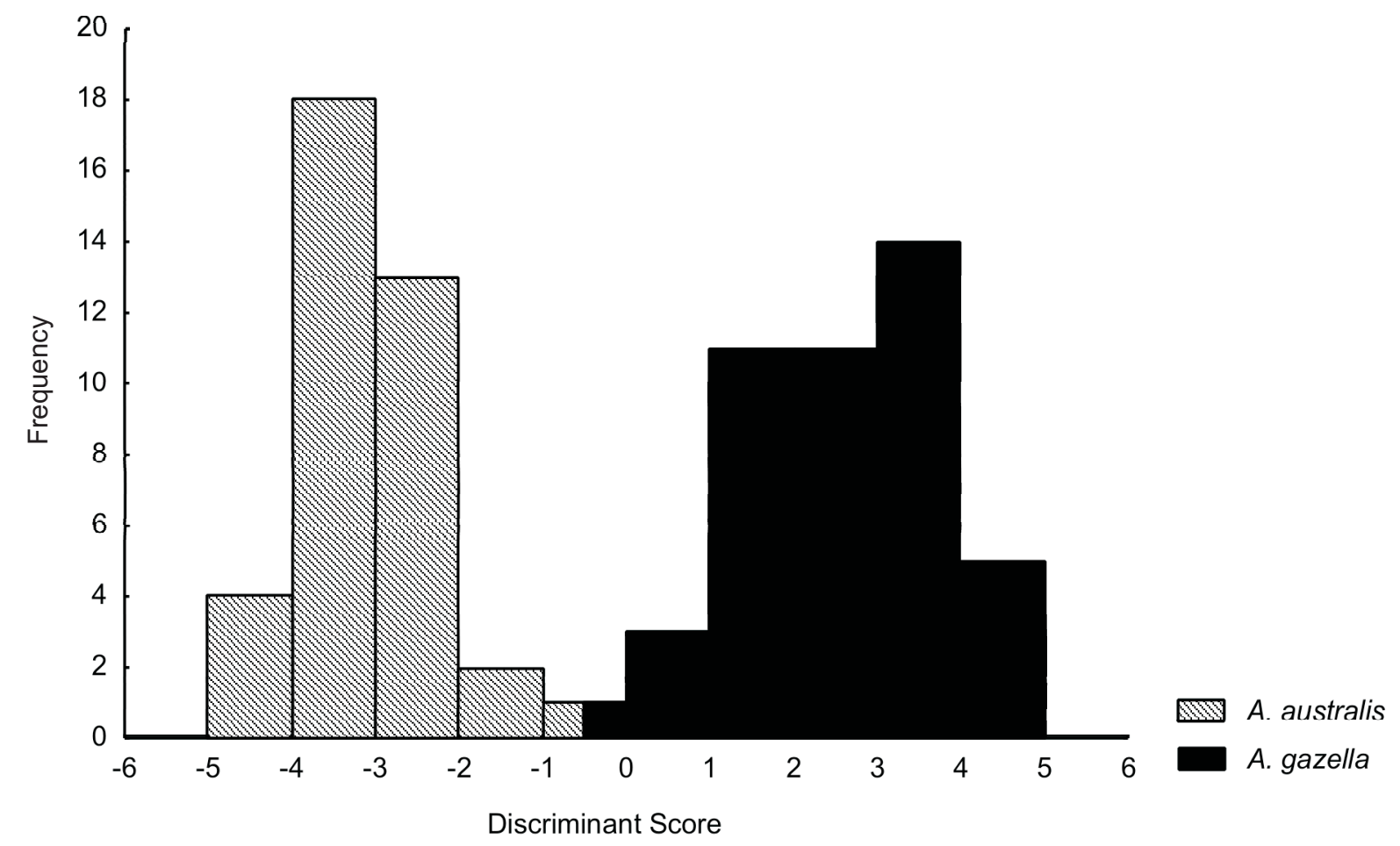

Fig. 3. Histogram of discriminant scores of adult males of A. gazella and A. australis.

postcanines. In contrast, postcanine teeth of $A$. gazella are small, unicuspid, and with a distinctive abrasion on their lingual surface. Prominent diastema which tend to be larger between the posterior premolars and between the molars are also characteristic of the species. A similar description of the postcanine dentition of A. gazella was made by Drehmer \& Oliveira (2000). Our visual inspection of postcanine teeth from skulls of both species 
were consistent with the above descriptions.

The multivariate analyses performed in the present study, based on cranial characters, corroborate the statement of REPENNING et al. (1971) that both A. gazella and $A$. australis are phenotipically distinct species. This study was the first to provide information on comparative cranial morphometrics between A. australis and A. gazella. However, it was restricted only to adult male specimens due to the lack of sufficient material of other sex/age groups. Several authors have previously stated that a statistical identification procedure for all species of the genus Arctocephalus would be of great benefit as these have proved to be morphologically similar. Future studies of this type, including a higher number of species of the genus, would clarify the degree of individual variation both within and between species.

Acknowledgements. To D. Verzi (Museo de La Plata), M. Clara (Facultad de Ciencias), A. Carlini (Instituto Antártico Argentino) and A. Mones (Museo Nacional de Historia Natural) for making available the specimens analyzed.

\section{REFERENCES}

Brunner, S. 1998a. Cranial morphometrics of the southern fur seals Arctocephalus forsteri and A. pusillus (Carnivora: Otariidae). Australian Journal of Zoology 46:67-108.

_. 1998b. Skull development and growth in the Southern fur seals Arctocephalus forsteri and A. pusillus doriferus (Carnivora: Otariidae). Australian Journal of Zoology 46:43-66.

2002. Geographic variation in skull morphology of adult Steller sea lions (Eumetopias jubatus). Marine Mammal Science 18(1):206-222.

Condy, P. R. 1978. Distribution, abundance and annual cycle of fur seals (Arctocephalus spp.) on the Prince Edward Islands. South African Journal of Wildlife Research 8: $159-168$

Csordas, S. E. 1962. The Kerguelen fur seal on Macquarie Island. Victorian Naturalist 79:226-229.

Daneri, G. A.; García Esponda, C. M. \& De Santis, L. J. M. 1997. A record of Arctocephalus australis (Zimmerman, 1783) (Carnivora, Otariidae) south of the Antarctic Convergence. Mammalia 61:451-454.

Drehmer, C. J. \& Oliveira, L. R. 2000. Syncranial osteology of Arctocephalus gazella (Pinnipedia, Otariidae) from Rio Grande do Sul, Brazil. Iheringia, Série Zoologia (88):51-59.

Kerley, G. I. H. \& Robinson, T. J. 1987. Skull morphometrics of male Antarctic and Subantarctic fur seals, Arctocephalus gazella and A. tropicalis, and their interspecific hybrids.
In: Croxall, J. P. \& Gentry, R. L. eds. Status, biology and ecology of fur seals. Seattle, NOAA Technical Report NMFS 51, p.121-131.

Kerley, G. I. H.; Allen, B. R. \& Bester, M. N. 2000. Skull morphometrics of male Subantarctic fur seals (Arctocephalus tropicalis) from Marion and Gough Islands. African Zoology 35:165-171.

KInG, J. E. 1954. The otariid seals of the Pacific Coast of America. Bulletin of the British Museum of Natural History, Zoology Series 2:311-337.

1959. The northern and southern populations of Arctocephalus gazella. Mammalia 23:19-40.

_- 1969. The identity of the fur seals of Australia. Australian Journal of Zoology 17:841-853.

1983. Seals of the world. London, British Museum (Natural History)/Cornell University Press. 240p.

King, C. M. \& Moody, J. E. 1982. The biology of the stoat (Mustela erminea) in the National Parks of New Zealand III. Morphometric variation in relation to grow, geographical distribution, and colonization. New Zealand Journal of Zoology 9:81-102.

Oliveira, L. R.; Malabarba, L. R. \& Majluf, P. 1999. Variação geográfica em crânios do lobo-marinho sul-americano Arctocephalus australis (Zimmermann, 1783) das populações do Brasil e Peru. Comunicações do Museu de Ciências e Tecnologia da PUCRS, Série Zoologia 12:179-192.

Oliveira, L. R.; Danilewicz, D.; Martins, M. B.; Ott, P. H.; Moreno, I. B. \& CAON, G. 2001. New Records of the Antarctic fur seal, Arctocephalus gazella (Peters, 1875) (Carnivora: Otariidae) for the Southern Brazilian Coast. Comunicações do Museu de Ciências e Tecnologia da PUCRS, Série Zoologia 14(2):201-207.

PAYNe, M. R. 1979. Fur seals Arctocephalus tropicalis and A. gazella crossing the Antarctic Convergence at South Georgia. Mammalia 43:93-98.

Pinedo, M. C. 1990. Ocorrência de pinípedes na costa brasileira. Garcia de Orta, Série Zoología 15:37-48.

ReIG, S. 1992. Geographic variation in Pine marten (Martes martes) and Beech marten (M. foina) in Europe. Journal of Mammalogy 73:744-769.

Reig, S. \& Ruprecht, L. 1989. Skull variability of Martes martes and Martes foina from Poland. Acta Theriologica 34:595-624.

Repenning, C. A.; Peterson, R. S. \& Hubbs, C. L. 1971. Contributions to the systematics of the southern fur seals, with particular reference to the Juan Fernández and Guadalupe species. Antarctic Research Series 18:1-34.

Sivertsen, E. 1954. A survey of the eared seals (Family Otariidae) with remarks on the Antarctic seals collected by $\mathrm{M} / \mathrm{K}$ "Norvegia" in 1928-1929. Scientific Results of the Norwegian Antarctic Expedition 36:1-76.

StatSoft, Inc. 1999. Statistica for Windows. Tulsa, StatSoft, Inc.

Recebido em fevereiro de 2004. Aceito em agosto de 2005. ISSN 0073-4721

Artigo disponível em: www.scielo.br/isz

Iheringia, Sér. Zool., Porto Alegre, 95(3):261-267, 30 de setembro de 2005 